\title{
ERRATUM
}

\section{To the article}

«Pulsed Dendritic Cells for the Therapy

of Experimental Glioma»

by I. V. Chekhonin, O. I. Gurina, S. A. Cherepanov, M. A. Abakumov, K. P. Ionova, D. K. Zhigarev, A. V. Makarov, and V. P. Chekhonin, Vol. 161, No. 6, pp. 792-796, October, 2016

The names of authors of the article should be:

I. V. Chekhonin, O. I. Gurina, S. A. Cherepanov, M. A. Abakumov, K. P. Ionova, D. I. Zhigarev, A. V. Makarov, and V. P. Chekhonin 